\title{
Factors influencing stream baseflow transit times in tropical montane watersheds
}

\author{
Lyssette E. Muñoz-Villers ${ }^{1}$, Daniel R. Geissert ${ }^{2}$, Friso Holwerda ${ }^{1}$, and Jeffrey J. McDonnell ${ }^{3,4}$ \\ ${ }^{1}$ Centro de Ciencias de la Atmósfera, Universidad Nacional Autónoma de México, Ciudad Universitaria, \\ Ciudad de México, México \\ ${ }^{2}$ Instituto de Ecología, A. C., Red de Ecología Funcional, Xalapa, Veracruz, México \\ ${ }^{3}$ Global Institute for Water Security, University of Saskatchewan, Saskatoon, Canada \\ ${ }^{4}$ School of Geosciences, University of Aberdeen, Aberdeen, UK \\ Correspondence to: Lyssette E. Muñoz-Villers (lyssette.munoz@atmosfera.unam.mx)
}

Received: 11 September 2015 - Published in Hydrol. Earth Syst. Sci. Discuss.: 27 October 2015

Revised: 11 April 2016 - Accepted: 12 April 2016 - Published: 27 April 2016

\begin{abstract}
Stream water mean transit time (MTT) is a fundamental hydrologic parameter that integrates the distribution of sources, flow paths, and storages present in catchments. However, in the tropics little MTT work has been carried out, despite its usefulness for providing important information on watershed functioning at different spatial scales in (largely) ungauged basins. In particular, very few studies have quantified stream MTTs or have related these to catchment characteristics in tropical montane regions. Here we examined topographic, land use/cover and soil hydraulic controls on baseflow transit times for nested catchments $\left(0.1-34 \mathrm{~km}^{2}\right)$ within a humid mountainous region, underlain by volcanic soil (Andisols) in central Veracruz (eastern Mexico). We used a 2-year record of bi-weekly isotopic composition of precipitation and stream baseflow data to estimate MTT. Land use/cover and topographic parameters (catchment area and form, drainage density, slope gradient and length) were derived from geographic information system (GIS) analysis. Soil water retention characteristics, and depth and permeability of the soil-bedrock interface were obtained from intensive field measurements and laboratory analysis. Results showed that baseflow MTTs ranged between 1.2 and 2.7 years across the 12 study catchments. Overall, MTTs across scales were mainly controlled by catchment slope and the permeability observed at the soil-bedrock interface. In association with topography, catchment form and the depth to the soil-bedrock interface were also identified as important features influencing baseflow MTTs. The greatest dif-
\end{abstract}

ferences in MTTs were found both within groups of small $\left(0.1-1.5 \mathrm{~km}^{2}\right)$ and large $\left(14-34 \mathrm{~km}^{2}\right)$ catchments. Interestingly, the longest stream MTTs were found in the headwater cloud forest catchments.

\section{Introduction}

The demand for fresh water is rapidly increasing in the humid tropics due to population growth. Nevertheless, in these regions - particularly the montane tropics - relative little process-based hydrological studies have been performed to quantify the states, stocks, flows, and residence times of water. These areas are especially prone to land degradation and deforestation for conversion to agricultural and pasture lands (Asner et al., 2009). Notably, tropical montane cloud forests (TMCF) are unique and hydrologically important ecosystems (Bruijnzeel, 2004), but are among the world's most threatened terrestrial ecosystems (Cayuela et al., 2006; Hamilton et al., 1995; Pope et al., 2015). Yet the hydrological impacts associated with land degradation and forest conversion at different scales remain poorly understood, thus hampering the development of effective local and regional strategies for water resources protection and management.

Stream water mean transit time (MTT) is an important hydrologic metric that integrates the variety of flow paths, storages, and runoff sources potentially existing in catchments. In humid temperate environments, MTTs estimated 
from stable isotopes have been used to broadly characterize the hydrological and biogeochemical behavior of catchments (McDonnell et al., 2010), providing important information on catchment resistance and resilience to climate change scenarios (Carey et al., 2010). In these same environments, significant progress has been made in exploring the linkages between baseflow MTTs and catchment characteristics, and the dominant factors controlling stream MTT variability across scales and regions. For example, McGuire et al. (2005) showed for the first time, the dependence of stream water mean residence time on catchment topographic indices (hillslope length and gradient) for multiple nested watersheds in western Oregon, USA. Further, Broxton et al. (2009) found that stream water isotope variability and estimated MTTs were both related to watershed aspect and slope in the Valles Caldera watershed, New Mexico, USA. In central Japan, Asano and Uchida (2012) showed that base flow MTT was mainly controlled by the depth of the hydrologically active layer (i.e., depth of the soil-bedrock interface), which was not necessarily related to catchment topography. Perhaps the most extensive work to date has been done in northeastern Scotland, where several studies have identified soil properties (soil type and permeability) as the main control on stream MTTs (Geris et al., 2015; Rodgers et al., 2005; Soulsby et al., 2006; Tetzlaff et al., 2009a). With the exception of the investigations carried out by McGlynn et al. (2013) in the Maimai watersheds in New Zealand, and more recently by Hale and McDonnell (2016) in the Alsea watershed study in the Oregon Coast Range, USA, which both showed strong positive relations between MTTs and catchment area, most studies to date have shown that landscape evolution and organization dictates rainfall-runoff processes in humid temperate environments.

In the humid tropics, isotope-inferred stream MTT studies have provided insights into the hydrological functioning of small forested catchments $\left(<0.3 \mathrm{~km}^{2}\right.$; Muñoz-Villers and McDonnell, 2012), and their sensitivity to land use conversion $\left(<1.8 \mathrm{~km}^{2}\right.$; Roa-García and Weiler, 2010). At larger scales $\left(>2\right.$ to $\left.77 \mathrm{~km}^{2}\right)$, the studies carried out in Ecuador by Crespo et al. (2012) and Timbe et al. (2014) have reported MTT values for various flowing water bodies (springs, creeks, tributaries, and rivers), but as yet, the factors controlling the stream water transit times in this and other montane regions of the humid tropics remain to be explored.

Here we build upon previous isotope work at our site in central Veracruz, Mexico, where large water storage capacities have been estimated ( $\sim 3$ years) for an old-growth TMCF upland catchment based on baseflow MTT (Muñoz-Villers and McDonnell, 2012). The present study is the first in the humid tropics that we are aware of that explores the relationship between stream water MTT and landscape characteristics across catchments ranging in different size areas (from 0.1 to $34 \mathrm{~km}^{2}$ ). Our tropical montane watersheds are underlain by volcanic soil substrates (Andisols). MTT was determined using a 2-year record of rainfall and stream water iso- tope data. We used metrics such as land cover, topographic parameters and hydrologic properties of the soil-bedrock profile to identify the factors controlling stream MTTs in this environment. Specifically we addressed the following research questions:

1. What are the stream mean transit times across catchment scales?

2. How do catchment area, topography, and subsurface hydrologic properties relate to stream transit times?

3. Does land cover have an effect on stream MTT variability?

4. Is there a dominant factor controlling stream water transit times in this mesoscale catchment?

\section{Materials and methods}

\subsection{Study site}

The fifth-order Los Gavilanes (LG) river catchment $\left(41 \mathrm{~km}^{2}\right.$; $19^{\circ} 28^{\prime} \mathrm{N}-97^{\circ} 01^{\prime} \mathrm{W}$ ) is located on the eastern (windward) slopes of the Cofre de Perote mountain. It is the main stream water supply for the city of Coatepec and surroundings ( $\sim 80000$ inhabitants). The landscape of this region is complex and strongly dissected by perennial streams draining catchments of different sizes. For this study, 12 catchments were selected, ranging in area from 0.1 to $34 \mathrm{~km}^{2}$ and located between 1300 and $3000 \mathrm{~m}$ a.s.l. (Fig. 1a). Table 1 summarizes the physical characteristics of the study catchments.

The mid- and upper parts of the LG catchment (1800$3000 \mathrm{~m}$ a.s.l.), where the majority of monitored headwaters are located, are characterized by short steep hillslopes covered mostly by pine-oak forest, mature and secondary tropical montane cloud forest, and pasture (Fig. $1 \mathrm{~b}$ and c). The lower portions of the LG catchment (1300-1800 m a.s.l.) are characterized by more gentle terrain covered by pasture, fragments of cloud forests on the steeper slopes and shaded coffee plantations below $1400 \mathrm{~m}$.

The general climate in the LG catchment is temperate humid with abundant summer rains (Garcia, 1988). About $80 \%$ of the annual rainfall falls as convective storms during the wet season (May-October), when the region is under the influence of the easterly trade wind flow. Maximum groundwater recharge and catchment runoff also occur during this season (cf. Muñoz-Villers and McDonnell, 2013). The relatively dry season (November-April) is characterized by light rains and/or fog and drizzle associated with the passage of cold fronts (Holwerda et al., 2010). Fog interception occurs exclusively during this time of year, and accounts for $\leq 2 \%$ of the annual rainfall for the upper part of the LG catchment (Holwerda et al., 2010; Muñoz-Villers et al., 2012, 2015).

The local climate varies markedly with elevation. At $1210 \mathrm{~m}$ a.s.l. (lower part of the LG catchment), the an- 
Table 1. Topographic characteristics of the 12 catchments $\left(0.1-34 \mathrm{~km}^{2}\right)$ investigated.

\begin{tabular}{lllccc}
\hline ID no. & Catchment & $\begin{array}{c}\text { Area } \\
\left(\mathrm{km}^{2}\right)\end{array}$ & $\begin{array}{c}\text { Stream } \\
\text { order }\end{array}$ & $\begin{array}{c}\text { Mean } \\
\text { elevation } \\
(\mathrm{m} \text { a.s.1.) }\end{array}$ & $\begin{array}{c}\text { Elevation } \\
\text { range } \\
(\mathrm{m} \text { a.s.1. })\end{array}$ \\
\hline 1 & MAT & 0.25 & 1 & 2160 & $2020-2300$ \\
2 & SEC & 0.12 & 2 & 2130 & $2040-2220$ \\
3 & PAS & 0.10 & 1 & 2400 & $2320-2480$ \\
4 & CATM1 & 0.46 & 2 & 2230 & $1980-2480$ \\
5 & CATM2 & 0.62 & 2 & 2230 & $1980-2480$ \\
6 & CATM3 & 1.9 & 3 & 2380 & $2000-2760$ \\
7 & CATM4 & 1.5 & 2 & 2240 & $1860-2620$ \\
8 & CATM5 & 4.1 & 2 & 2050 & $1340-2760$ \\
9 & CATM6 & 8.9 & 4 & 1980 & $1340-2620$ \\
10 & PUENTE ZARAGOZA & 13.5 & 4 & 2030 & $1300-2760$ \\
11 & HUEHUEYAPAN & 19.7 & 4 & 2120 & $1300-2940$ \\
12 & LOS GAVILANES & 33.5 & 5 & 2120 & $1300-2940$ \\
\hline
\end{tabular}
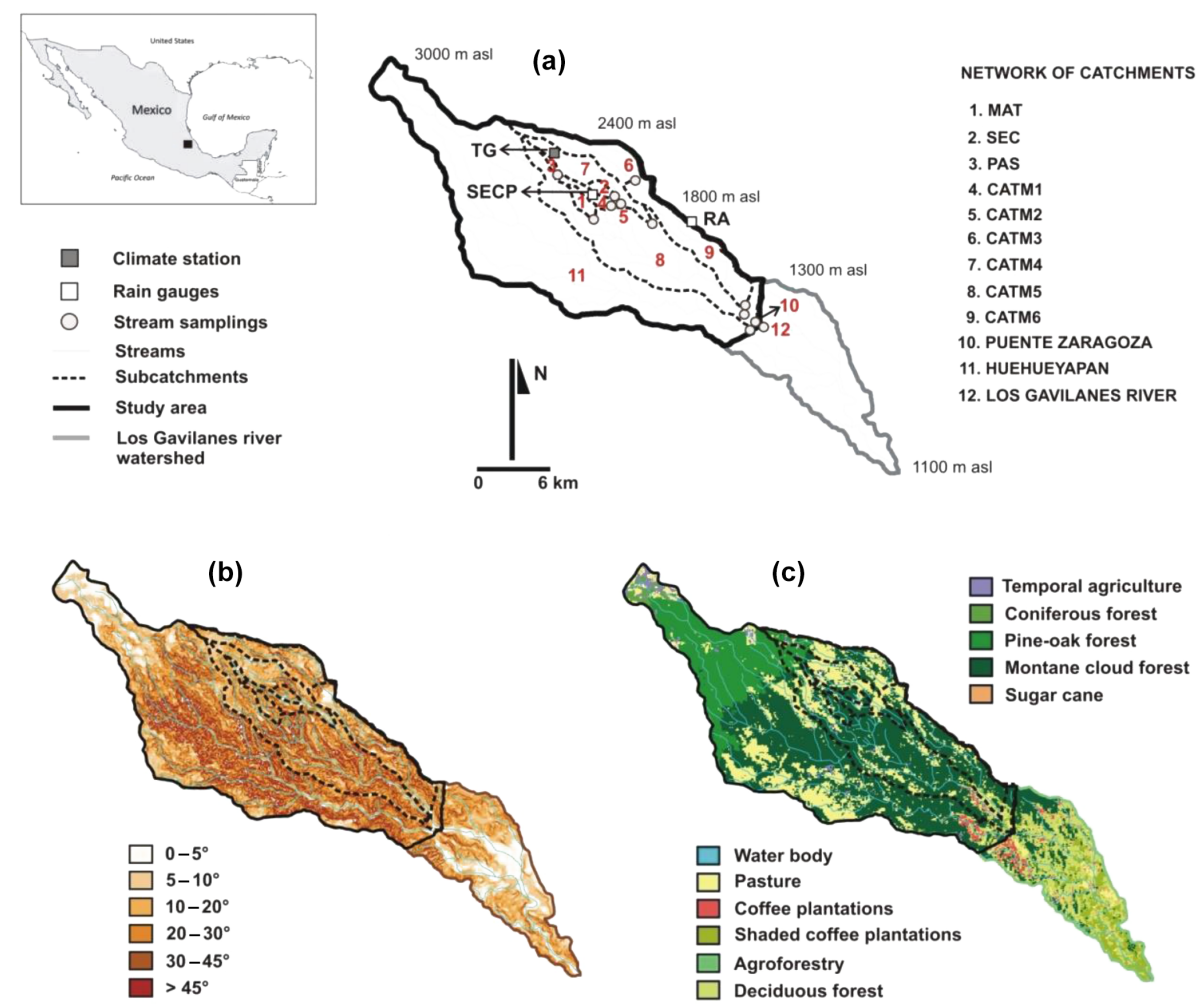

Figure 1. Location of the study site in central Veracruz, eastern Mexico, and maps of the Los Gavilanes catchment showing (a) the stream and rain water collection points, (b) slopes, and (c) land covers (see text for further explanation).

nual mean daily temperature is $19^{\circ} \mathrm{C}$. Corresponding mean annual rainfall and reference evapotranspiration $\left(\mathrm{ET}_{0}\right)$ are 1385 and $1120 \mathrm{~mm}$, respectively (Holwerda et al., 2013). At $2100 \mathrm{~m}$ a.s.1. (middle part), the annual mean daily temperature is $15^{\circ} \mathrm{C}$, and mean annual rainfall and $\mathrm{ET}_{0}$ are 3185 and $855 \mathrm{~mm}$, respectively (Goldsmith et al., 2012; Muñoz-Villers et al., 2012). Finally, at $3000 \mathrm{~m}$ a.s.l. (upper part), mean an- nual temperatures range between 5 and $10^{\circ} \mathrm{C}$, and mean annual rainfall is $1900 \mathrm{~mm}$ (SMN, 2014).

Andisols derived from volcanic ashes are the dominant type of soil across the LG catchment. These soils are characterized by low bulk density, high permeability, high water retention capacity, and high organic matter content (GómezTagle Jr. et al., 2011). Soil profiles are usually deep, well developed and multilayered (A, A/B, Bw, Bw/C), with silt loam 
and silty clay loam as the dominant textures (Gómez-Tagle Jr. et al., 2011). The parental material is permeable, consisting of moderately weathered andesitic breccias, underlain, in turn, by semi-permeable saprolite that has been weathered from fractured andesitic-basaltic bedrock (cf. Muñoz-Villers and McDonnell, 2012).

\subsection{Field data collection and analysis}

\subsubsection{Rainfall measurements}

To quantify daily precipitation and its spatial variation along the altitudinal gradient, rainfall was measured at 1560, 2100 and $2400 \mathrm{ma.s.1}$. (Fig. 1a). For the sites at $1560 \mathrm{~m}$ (hereafter RA) and $2100 \mathrm{~m}$ (hereafter SECP), stand-alone tipping bucket rain gauges of the type RG2M (Onset ${ }^{\circledR}$ ) and Casella CEL, Inc., respectively, were used (both with a resolution of $0.2 \mathrm{~mm}$ ). For the site at $2400 \mathrm{~m}$, rainfall was measured with an ARG100 tipping bucket rain gauge (environmental measurements; $0.2 \mathrm{~mm}$ ) as part of a meteorological station (hereafter TG; Fig. 1a). The signals from the standalone gauges were stored in an $\mathrm{HOBO}^{\circledR}$ pendant event logger $\left(\right.$ Onset $\left.{ }^{\circledR}\right)$, whereas for the gauge in the weather station a CR1000 data logger (Campbell Scientific) was used. Measurements at SECP were made continuously from July 2006 to November 2010, whereas measurements at RA and TG covered the period of isotope sampling (see below).

\subsubsection{Collection and analysis of rain and stream water samples}

To establish the records of $\delta^{2} \mathrm{H}$ and $\delta^{18} \mathrm{O}$ isotope composition of precipitation and streamflow, samplings during nonstorm conditions were carried out over two hydrological years (May 2008-April 2010). Paired with the tipping bucket rain gauges, samples of bulk rainfall were collected using a sampler consisting of a $95 \mathrm{~mm}$ diameter funnel assembled to a $40 \mathrm{~mm}$ diameter, and $400 \mathrm{~mm}$ long transparent collection tube. The tube contained a float to minimize evaporation. In addition, the rain water collector was inserted into a $75 \mathrm{~mm}$ diameter PVC pipe wrapped with bubble foil insulation to protect the collected water against sunlight and minimize temperature variations. Rainwater sampling intervals ranged between 1 and 25 days, depending on rainfall amount and frequency. For logistical reasons, rainwater collection at the RA site was only possible from March 2009 to April 2010. The missing isotope data (10 months) were completed using a linear regression with data from the SECP site $\left(r^{2}=0.95\right)$.

Previous hydrological work at our research site has shown that baseflow is the dominant streamflow component ( $\sim 90 \%$ ). Furthermore, isotope and chemical-based hydrograph separation for a series of storms and for catchments dominated by different land covers showed that rainfallrunoff responses are mainly dominated by groundwater sources (Muñoz-Villers and McDonnell, 2012, 2013). For these reasons, we focused our stream sampling on baseflow. Grab samples of base flow were collected every 2 weeks at the outlets of the 12 study catchments. These included nine sampling points representing headwaters up to fourth-order streams (numbers 1-9; Fig. 1a), two main tributaries of the LG river (10 and 11), and the main river (12).

All water samples were collected in $30 \mathrm{~mL}$ borosilicate glass vials with polycone sealing cap to prevent evaporation. The samples were analyzed for $\delta^{2} \mathrm{H}$ and $\delta^{18} \mathrm{O}$ on a laser liquid-water isotope spectrometer (Version 2, Los Gatos Research, Inc.) in the Hillslope and Watershed Hydrology Lab at Oregon State University, USA. The isotope values are expressed in permil (\%o) relative to the Vienna Standard Mean Ocean Water (VSMOW). The precision of $\delta^{2} \mathrm{H}$ and $\delta^{18} \mathrm{O}$ measurements was 0.3 and $0.1 \%$, respectively.

\subsection{Transit time model}

Bi-weekly $\delta^{2} \mathrm{H}$ signatures of stream water and rainfall were used to estimate base flow MTT and transit time distribution (TTD) for each of the study catchments. First, 2week volume-weighted means (VWMs) of rainfall isotope composition were calculated for each of the three sampling sites. Second, we followed the McGuire et al. (2005) approach to compare the average isotope signature of baseflow for each study catchment with that of rainfall, and so to identify the elevation at which most recharge occurs. For this, we calculated 2-year averages, and determined for each catchment which of the rainfall time series had its average $\delta^{2} \mathrm{H}$ value closest to the average $\delta^{2} \mathrm{H}$ baseflow value. The overall mean $\delta^{2} \mathrm{H}$ base flow value was $-44.9 \%$ (range: -50.2 to $-41.0 \%$ across all catchments), whereas rainfall at TG, SECP, and RA had volume-weighted mean $\delta^{2} \mathrm{H}$ values of $-43.0,-37.6$, and $-33.5 \%$, respectively. Hence, for all of the study catchments, MTT simulations were carried out using the rain isotope data from either TG or SECP. Further, this approach was supported by the fact that both the TG and SECP sites are located at those elevations in the LG catchment where most groundwater recharge occurs, as determined by previous water balance studies (Muñoz-Villers et al., 2012, 2015).

The $\delta^{2} \mathrm{H}$ precipitation data collected over 2 hydrological years (May 2008-April 2010) may be too short to properly constrain stream base flow MTT estimates (cf. Hrachowitz et al., 2009). However, precipitation at our site shows a marked seasonal pattern (Holwerda et al., 2010; Muñoz-Villers et al., 2012). In addition, rainfall isotope signatures show a strong and consistent variation with rainfall amount (Goldsmith et al., 2012). Therefore, to generate an artificial warm-up period required for the MTT model simulations, we followed the approach of Hrachowitz et al. (2009) and repeated our measured 2-year rainfall time series 15 times (cf. MuñozVillers and McDonnell, 2012). We then used a lumped parameter convolution model to predict the $\delta^{2} \mathrm{H}$ output for 
the stream water as a weighted sum of its respective past $\delta^{2} \mathrm{H}$ measured input in precipitation (Maloszewski and $\mathrm{Zu}$ ber, 1993). Mathematically, the stream water outflow composition at any time, $\delta_{\text {out }}(t)$, consisted of past inputs lagged $\delta_{\text {in }}(t-\tau)$ and weighted by the transfer function $g(\tau)$, representing its lumped TTD (Maloszewski and Zuber, 1982):

$\delta_{\text {out }}(t)=\int_{0}^{\infty} g(\tau) \delta_{\text {in }}(t-\tau) d \tau$,

where $\tau$ are the lagged times between the input and output tracer composition. The weighting function or TTD describes the travel time of the water from the ground surface to an outflow location (i.e., the catchment outlet) (McGuire and McDonnell, 2010).

In this study, we used the most basic TTD models (exponential, gamma, and dispersion), which require only one or two distribution parameters to be optimized and have been successfully applied in other studies (e.g., McGuire et al., 2005). The performance of different TTD functions for each of the 12 study catchments was evaluated using the transfer function hydrograph separation model TRANSEP (McGuire and McDonnell, 2010; Weiler et al., 2003). This model utilizes the generalized likelihood uncertainty estimation (GLUE) methodology (Freer et al., 1996) based on Monte Carlo simulations to determine the identifiability of the individual parameters. Our Monte Carlo analysis of each TTD consisted of 10000 runs. Model performance was assessed using the Nash-Sutcliffe efficiency $E$ (Nash and Sutcliffe, 1970), based on the best agreement parameter value, where a value of 1 would indicate a perfect fit. Parameter uncertainty was defined as the range between 10th and 90th percentile value for the best $20 \%$ performing parameter sets based on $E$ (McGuire and McDonnell, 2010; Seibert and McDonnell, 2010). The overall performance of the TTD models was evaluated using the root mean square error (RMSE).

\subsection{Terrain analysis}

To evaluate whether landscape characteristics had an influence on base flow MTT, several metrics describing catchment topographic and morphometric features were calculated in Integrated Land Water Information System (ILWIS), version 3.3, a raster and vector geographic information system (GIS). Catchment area was obtained by delineating and extracting each catchment boundary using a digital contour elevation map $(10 \mathrm{~m} \times 10 \mathrm{~m}$ resolution $)$. Land cover was obtained from a regional land cover/use raster map $(20 \mathrm{~m} \times 20 \mathrm{~m}$ ) elaborated by Muñoz-Villers and LópezBlanco (2008), using satellite images and ground truth verification data. For vegetation cover, each catchment was classified in one of the following four categories: (1) $>90 \%$ covered by TMCF; (2) > $60 \%$ covered by any type of forest (pine-oak, TMCF); (3) > 90\% covered by pasture; and
(4) even mixture $(\sim 50-50 \%)$ of pasture and any type of forest.

Catchment form factor (a measure of catchment shape), drainage density, slopes, and hillslope length were calculated using topographic maps (scale 1: 20000 ) and a $10 \mathrm{~m} \times 10 \mathrm{~m}$ digital elevation model (DEM). Catchment form factor $\left(R_{\mathrm{f}}\right)$ and drainage density $\left(D_{\mathrm{d}}\right)$ were calculated following Horton (1932). Hillslope length was obtained as the average distance between catchment ridge top and valley bottom. Horizontal and vertical gradients of each pixel in the DEM were used to calculate the mean and the percentage distribution of slopes in each catchment, using for the latter the following six classes: 0-5, 5-10, 10-20, 20-30, 30-45, and $>45^{\circ}$.

\subsection{Soil sampling and analysis}

Field surveys, soil samplings, and subsequent laboratory analysis were conducted from May 2011 to May 2012. First, hillslope forms (ridge top, mid- and valley bottom) were derived in GIS using topographic analysis algorithms (Jenness, 2006) and then overlaid with catchment boundaries. From the intersection of the polygon units thirty-two soil toposequences were selected, distributed mostly in the mid- and lower portions of the LG catchment because access to the upper part was very difficult. At each toposequence, soil auger holes up to $2.2 \mathrm{~m}$ deep were performed from ridge top to valley bottom to determine the organization of soil layers along the hillslope. Soil penetration resistance was also measured down to $2 \mathrm{~m}$ using a dynamic cone penetrometer, following the design and method of Herrick and Jones (2002).

At selected toposequences, soil profile pits of approximately $1.5 \mathrm{~m} \times 1.5 \mathrm{~m} \times 2 \mathrm{~m}$ (length, width, and depth, respectively; 43 in total) were excavated for detailed soil descriptions following the method of Schoeneberger et al. (2002). In addition, undisturbed soil core samples $(n=3)$ at the soil-bedrock interface in each soil profile pit were taken to determine saturated hydraulic conductivity $\left(K_{\mathrm{S}}\right)$ in the laboratory using the constant-head method. Further, a pedotransfer function, correlating the observed $K_{\mathrm{s}}$ and penetration resistance values, was used to extrapolate $K_{\mathrm{s}}$ of the least permeable layer to the catchment scale.

In each soil pit, soil samples from the A and B horizons (solum) were collected for laboratory analysis. Bulk density was determined from samples taken with cylindrical stainless steel cores of $100 \mathrm{~cm}^{3}$ in each horizon $(n=3)$, and dried at $105^{\circ} \mathrm{C}$ until constant weight. For soil moisture content at field capacity, undisturbed samples from $5 \mathrm{~cm} \times 1 \mathrm{~cm}$ rings (diameter and height; $n=3$ ) were collected, then weighed after reaching saturation and equilibration (normally within $48 \mathrm{~h}$ ), and placed in a pressure-plate apparatus at $30 \mathrm{kPa}$. From water retention at field capacity and bulk density values, the amount of water held in the solum (in mm) was calculated. All laboratory analyses were performed in the Soil Laboratory of the Instituto de Ecología A. C., Xalapa, Veracruz. 
Based on the observed range of depths to soil-bedrock interface (DSBI), this variable was divided in four classes: very shallow $(<50 \mathrm{~cm}$ depth), shallow $(>50-100 \mathrm{~cm})$, moderate deep $(100-200 \mathrm{~cm})$, and relatively deep $(>200 \mathrm{~cm})$. Soil $K_{\mathrm{S}}$ and water retention (WR) capacity categories were defined for each site and hillslope sequence. The $K_{\mathrm{s}}$ classes were obtained from the Soil Hydrology Group of the National Engineering Handbook, Part 630 (NRCS-USDA, 2007), and partly modified based on the hydrology of soil types (HOST) classification system (Boorman et al., 1995). The WR capacity classes were defined on ad hoc ranges. Based on relationships between the soil hydrologic properties and geo-forms, the data were extrapolated to the entire LG catchment.

Finally, to evaluate differences in the isotopic composition and deuterium excess $\left(d\right.$-excess $=\delta^{2} \mathrm{H}-8 \cdot \delta^{18} \mathrm{O}$; Dansgaard, 1964) values for rainfall and stream water across sites, we used ANOVA $t$ tests. Statistical relationships between baseflow MTT, depth, and permeability at the soil-bedrock interface, soil water retention and landscape characteristics (land cover and topographic variables) were tested using Spearman's rank order correlations. All statistics were evaluated at the 0.05 confidence level and conducted in SigmaPlot (version 12, Systat Software Inc.).

\section{Results}

\subsection{Isotopic composition of rainfall and stream water}

From May 2008 to April 2010, mean annual precipitation varied from $2670 \mathrm{~mm}$ at RA $(1560 \mathrm{~m}), 3476 \mathrm{~mm}$ at SECP $(2100 \mathrm{~m})$ to $3264 \mathrm{~mm}$ at TG $(2400 \mathrm{~m})$. The average of $3476 \mathrm{~mm}$ measured at the SECP is somewhat higher (9\%) than the average of $3185 \pm 305 \mathrm{~mm}$ (SD) measured at that same site between November 2005 and November 2009 (see above). Nevertheless, the rather small difference suggests that the 2 years of data used in this study are representative of the longer rainfall pattern. For the other sites, no other data than those given here are available.

Rainfall showed a clear seasonal pattern, with $80 \%$ on average falling during the wet season (May-October). During the same period, a wide range of variation in the biweekly rainfall isotope values was found across elevations. The largest variation $\left(118 \%\right.$ o for $\delta^{2} \mathrm{H}$ and $17 \%$ for $\delta^{18} \mathrm{O}$ ) and most negative (depleted) values $\left(-110 \%\right.$ for $\delta^{2} \mathrm{H}$ and $-16 \%$ o for $\delta^{18} \mathrm{O}$ ) were observed at the highest altitude $(2400 \mathrm{~m})$. With decreasing altitude, rainfall isotope values became more positive (enriched) and their range of variation smaller (Fig. 2a). However, differences in rainfall isotopic composition among elevations were only suggested for $\delta^{18} \mathrm{O}$ $(p=0.031)$. Mean annual deuterium excess ( $d$-excess) values of rainfall increased from 15 to $17 \%$ with elevation, but differences among sites were not significant ( $p \geq 0.05)$.

Across all sites, $\delta^{2} \mathrm{H}$ and $\delta^{18} \mathrm{O}$ rainfall signatures in the wet season $(-32.3 \pm 25.7 \%$ and $-5.9 \pm 3.2 \%$ SD, respec-

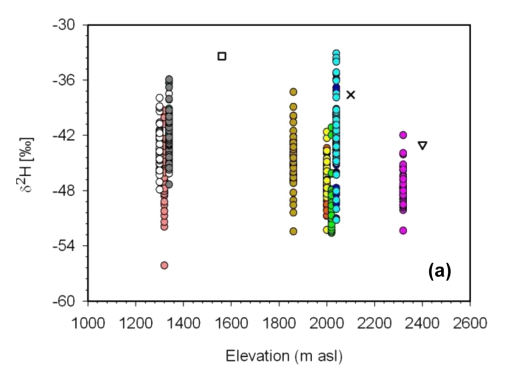

VWM Precip RA (1560 masl)
VWM Precip SECP (2100 masl) VWM Precip TG (2400 masl)
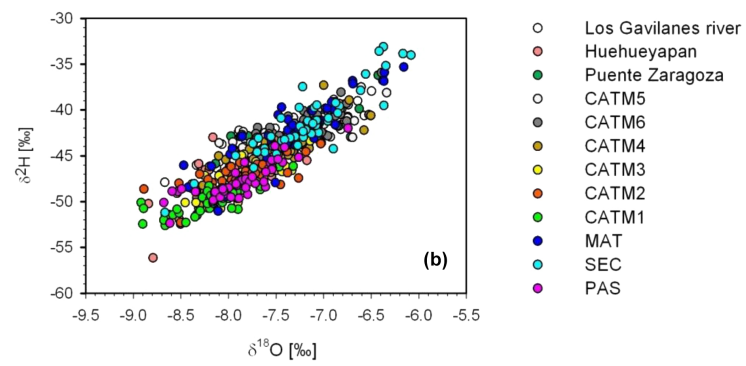

CATM6

CATM4

CATM3

CATM2
CATM1

SEC

PAS

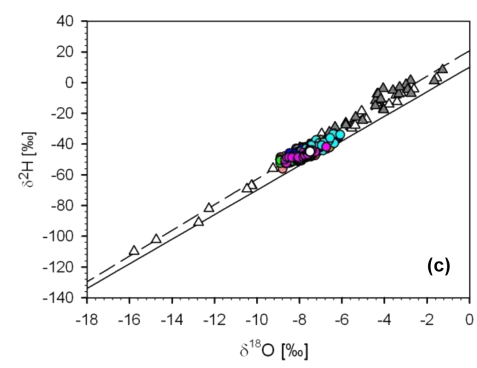

LMWL

GMWL

VWM Precip TG

Mean all streams

TG Precip - dy season

TG Precip - wet season

Figure 2. (a) Relationship between $\delta^{2} \mathrm{H}$ signatures of stream base flow and elevation of the catchment outlets (i.e., the sampling locations), and volume-weighted means (VWMs) of the deuterium composition of rainfall at the three elevations within the Los Gavilanes river catchment; (b) $\delta^{18} \mathrm{O}$ versus $\delta^{2} \mathrm{H}$ signatures of baseflow from the 12 catchments investigated; and (c) isotope $\left(\delta^{18} \mathrm{O}\right.$ versus $\left.\delta^{2} \mathrm{H}\right)$ signatures of rainfall and stream baseflow. The local meteoric water line (LMWL; dashed line) is based on the 2008-2010 precipitation at TG, and reads: $\delta^{2} \mathrm{H}=8.36 \cdot \delta^{18} \mathrm{O}+20.37$; the solid line represents the global meteoric water line (GMWL): $\delta^{2} \mathrm{H}=8 \cdot \delta^{18} \mathrm{O}+10$.

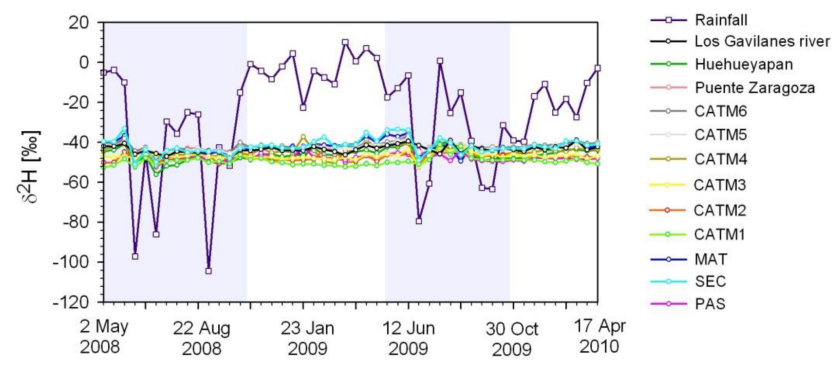

Figure 3. Bi-weekly values of $\delta^{2} \mathrm{H}$ composition of stream baseflow for each of the 12 study catchments, and corresponding values of deuterium composition of rainfall at $2400 \mathrm{~m}$ (TG) for the period between May 2008 and April 2010. The shaded areas indicate the wet seasons. 
Table 2. Annual, and wet and dry season means of the isotopic composition of rainfall (three sites) and stream water (12 sampling locations) plus corresponding values of $d$-excess, as calculated from 2 years of data (April 2008-May 2010).

\begin{tabular}{|c|c|c|c|c|c|c|c|c|c|}
\hline \multirow[t]{2}{*}{ Rainfall } & \multicolumn{3}{|c|}{$\begin{array}{l}\text { VWM } \\
\text { annual }\end{array}$} & \multicolumn{3}{|c|}{$\begin{array}{c}\text { VWM } \\
\text { wet season }\end{array}$} & \multicolumn{3}{|c|}{$\begin{array}{c}\text { VWM } \\
\text { dry season }\end{array}$} \\
\hline & $\delta^{2} \mathrm{H}$ & $\delta^{18} \mathrm{O}$ & $d$-excess & $\delta^{2} \mathrm{H}$ & $\delta^{18} \mathrm{O}$ & $d$-excess & $\delta^{2} \mathrm{H}$ & $\delta^{18} \mathrm{O}$ & $d$-excess \\
\hline TG (2400 m) & -43.0 & -7.5 & 17.0 & -48.2 & -8.0 & 15.8 & -23.7 & -5.5 & 20.3 \\
\hline $\operatorname{SECP}(2100 \mathrm{~m})$ & -37.6 & -6.7 & 16.0 & -43.6 & -7.4 & 15.6 & -18.9 & -4.6 & 17.9 \\
\hline \multirow[t]{3}{*}{$\mathrm{RA}(1560 \mathrm{~m})$} & -33.4 & -6.1 & 15.4 & -44.0 & -7.4 & 15.2 & -12.2 & -3.7 & 17.4 \\
\hline & \multicolumn{3}{|c|}{ Mean annual } & \multicolumn{3}{|c|}{ Mean wet season } & \multicolumn{3}{|c|}{ Mean dry season } \\
\hline & $\delta^{2} \mathrm{H}$ & $\delta^{18} \mathrm{O}$ & $d$-excess & $\delta^{2} \mathrm{H}$ & $\delta^{18} \mathrm{O}$ & $d$-excess & $\delta^{2} \mathrm{H}$ & $\delta^{18} \mathrm{O}$ & $d$-excess \\
\hline MAT & -42.5 & -7.3 & 15.9 & -43.1 & -7.4 & 16.1 & -41.8 & -7.2 & 15.8 \\
\hline SEC & -41.8 & -7.2 & 15.8 & -42.5 & -7.3 & 15.9 & -40.9 & -7.0 & 15.1 \\
\hline PAS & -47.7 & -7.9 & 15.5 & -47.7 & -7.9 & 15.5 & -47.6 & -7.8 & 14.8 \\
\hline CATM1 & -49.4 & -8.1 & 15.4 & -48.9 & -8.1 & 15.9 & -50.1 & -8.1 & 14.7 \\
\hline CATM2 & -47.2 & -7.8 & 15.2 & -47.0 & -7.8 & 15.4 & -47.4 & -7.8 & 15.0 \\
\hline CATM3 & -46.8 & -7.8 & 15.6 & -46.4 & -7.7 & 15.2 & -47.4 & -7.9 & 15.8 \\
\hline CATM4 & -44.8 & -7.5 & 15.2 & -42.5 & -7.6 & 18.3 & -44.3 & -7.4 & 14.9 \\
\hline CATM5 & -42.5 & -7.3 & 15.9 & -42.8 & -7.3 & 15.6 & -42.1 & -7.3 & 16.3 \\
\hline CATM6 & -41.8 & -7.2 & 15.8 & -42.2 & -7.2 & 15.4 & -41.3 & -7.2 & 16.3 \\
\hline PUENTE ZARAGOZA & -42.1 & -7.3 & 16.3 & -42.5 & -7.3 & 15.9 & -41.7 & -7.2 & 15.9 \\
\hline HUEHUEYAPAN & -46.1 & -7.7 & 15.5 & -46.6 & -7.8 & 15.8 & -45.4 & -7.7 & 16.2 \\
\hline LOS GAVILANES & -43.3 & -7.4 & 15.9 & -43.7 & -7.4 & 15.5 & -43.0 & -7.4 & 16.2 \\
\hline
\end{tabular}

tively) were significantly depleted as compared to the dry season $(-15.6 \pm 13.6$ and $-4.3 \pm 1.7 \% ; p \leq 0.05)$ (Fig. 3). Stream water isotopic composition followed the seasonal pattern as observed for precipitation; however, values were damped (range: -49.4 to $-41.8 \%$ for $\delta^{2} \mathrm{H}$ and -8.1 to $-7.2 \%$ for $\delta^{18} \mathrm{O}$; Fig. 3) as compared to rainfall (range: -106 to $10 \%$ for $\delta^{2} \mathrm{H}$ and -15 to $-1 \%$ for $\delta^{18} \mathrm{O}$, respectively). For all stream water sites, differences in isotope composition between the dry and wet seasons were not statistically significant $(p \geq 0.05)$.

Unlike rainfall, there were no distinct differences in the isotope signatures of the streams, despite the altitude difference of more than $1000 \mathrm{~m}$ between the upland headwaters and the downstream LG river tributaries (Fig. 2b). During the wet season, $d$-excess values in the streams were rather constant across all sites, whereas during the dry season values were slightly enriched at lower elevations as compared to upper elevations (Table 2).

Figure $2 \mathrm{c}$ shows that all samples of precipitation and stream water fall along the local meteoric water line (LMWL), with $d$-excess values consistently above $10 \%$ (range of rainfall: 10.7 to $24.2 \%$, and streams: 10.4 to $22.5 \%$ ). The fact that the rainfall and stream baseflow samples had very similar $d$-excess ranges indicates that the catchment water input-output was little affected by evaporation.

\subsection{Land cover, topography, and soil hydraulic properties}

Our GIS analysis showed that approximately $70 \%$ of the LG catchment was covered by some type of forest. Eight out of the 12 study catchments were located in the middle and upper portions of the LG catchment, which are characterized by moderate to steep terrain. These eight catchments ranged in size between 0.1 and $14 \mathrm{~km}^{2}$, and were covered predominantly by mature and secondary TMCF (>50\%; Table 3 ). Forest was also the dominant land cover in one of the two tributary catchments (Huehueyapan) and in the LG catchment itself. In these two catchments, the upper part was dominated by pine-oak $(>2500 \mathrm{~m})$, the middle part by TMCF and pasture, meanwhile coffee plantations and forest fragments characterized the lower part $(<1400 \mathrm{~m})$. Two out of the 12 catchments were dominated by pasture (having areas of 0.1 and $\left.1.5 \mathrm{~km}^{2}\right)$, and only one catchment $\left(1.9 \mathrm{~km}^{2}\right.$ of area) was covered by even portions of forest and pasture.

Hillslope lengths were shortest (113 $\mathrm{m}$ on average) in the smallest catchments $\left(0.1-1.5 \mathrm{~km}^{2}\right)$, and longest $(273 \mathrm{~m})$ in the largest ones (14-34 km² ; Table 3). Slopes of intermediate length $(217 \mathrm{~m})$ were found in the $4-9 \mathrm{~km}^{2}$ catchments. Mean slope was $32 \pm 5^{\circ}$ across all catchments. The dominant categories of slopes were $10-20$ and $20-30^{\circ}$. Within these groups, the headwater mature and secondary cloud forest catchments (mature (MAT) and secondary (SEC); $\leq 0.25 \mathrm{~km}^{2}$ ) showed the highest proportions of the abovementioned slope categories. The pasture headwater catch- 
ment (PAS; $0.1 \mathrm{~km}^{2}$ ) had the highest percentage $(46 \%)$ of gentle slopes $\left(0-10^{\circ}\right)$, meanwhile the $20 \mathrm{~km}^{2}$ Huehueyapan tributary catchment showed the highest proportion $(33 \%)$ of very steep slopes $\left(>30^{\circ}\right)$.

The $R_{\mathrm{f}}$ ranged between 0.071 (CATM1 and CATM5) and 0.231 (SEC). $D_{\mathrm{d}}$ ranged from 1.3 to $8.0 \mathrm{~km} \mathrm{~km}^{-2}$. Low $D_{\mathrm{d}}$ values $\left(2.4 \pm 0.4 \mathrm{~km} \mathrm{~km}^{-2}\right)$ were found at the larger catchments $\left(14-34 \mathrm{~km}^{2}\right)$ whereas higher $D_{\mathrm{d}}$ values $\left(5.3 \pm 2.4 \mathrm{~km} \mathrm{~km}^{-2}\right)$ characterized the smaller catchments $\left(0.1-9 \mathrm{~km}^{2}\right.$; Table 3$)$.

Soil depth and WR capacity of the solum were greatest in hillslopes located in the middle portion of the LG catchment; maximum WR values were observed in the headwater MAT and SEC forest catchments, and in other small catchments $<0.5 \mathrm{~km}^{2}$ dominated by TMCF (category 15 ; Fig. $4 \mathrm{a}$ ). Catchments with areas of approximately $2 \mathrm{~km}^{2}$ were dominated $(>50 \%)$ by soil depths and WR capacities ranging between 1.0 and $1.5 \mathrm{~m}$ and 580 and $850 \mathrm{~mm}$, respectively (category 14). Shallower soil depths (from 0.5 to $1 \mathrm{~m}$ ) and reduced WR values (from 310 to $510 \mathrm{~mm}$; category 13 ) characterized the slope areas (46\% on average) of the larger catchments $\left(9-34 \mathrm{~km}^{2}\right)$. CATM5 showed the highest proportion of area (33\%) covered by very shallow soils and relatively low water retentions (category 12).

Across all sites, the DSBI ranged from 0.5 to more than $2 \mathrm{~m}$, and soil saturated $K_{\mathrm{S}}$ at the interface ranged from 1 to nearly $40 \mathrm{~mm} \mathrm{~h}^{-1}$. However, for the majority of the catchments, the DSBI was between 1.0 and $1.5 \mathrm{~m}(\sim 65 \%$ of the catchment area on average), with corresponding $K_{\mathrm{S}}$ values between 1 and $15 \mathrm{~mm} \mathrm{~h}^{-1}$ (category 2C; Fig. 4b). Notably, the SEC was dominated by DSBIs between 1 and $2 \mathrm{~m}(70 \%$ of the catchment area); at some locations in this catchment DSBI was greater than $2 \mathrm{~m}$, with permeabilities at the soilbedrock interface higher than $36 \mathrm{~mm} \mathrm{~h}^{-1}$ (Categories 2A and $1 \mathrm{~A})$. In contrast, the Huehueyapan catchment showed the highest percentage of area $(30 \%)$ covered by very low DSBI values $(0.5-1.0 \mathrm{~m}$ on average) of all catchments, but $K_{\mathrm{S}}$ ranged from 4 to $36 \mathrm{~mm} \mathrm{~h}^{-1}$ (Categories $4 \mathrm{C}$ and $3 \mathrm{~B}$ ).

\subsection{Stream baseflow MTTs and their relationship with catchments characteristics}

Estimated baseflow MTT ranged between 1.2 and 2.7 years across the 12 study catchments. Note the TTD model that we reported for a particular catchment was the one that best fitted the observed baseflow data (Table 4). The root mean square error (RMSE) and Nash-Sutcliffe efficiency value $(E)$ for these model results ranged from 0.8 to $1.5 \% \circ\left(\delta^{2} \mathrm{H}\right)$ and 0.42 to 0.69 , respectively. Table 4 provides further details on the values of the TTD parameters and the uncertainty bounds.

Catchment form, slope, land cover, and depth to soilbedrock interface explained each about $50 \%$ of the variance of baseflow MTT across catchments (Fig. 5). The positive correlation found between $R_{\mathrm{f}}$ and baseflow MTT suggests that catchments with narrow and elongated shapes lead to shorter transit times (Table 5; Fig. 5a). Long MTTs were positively correlated with moderately steep catchments (particularly where slopes between 20 and $30^{\circ}$ predominated; Fig. 5c). Conversely, short MTTs were most strongly related to catchments with high proportions of gently slopes (between 5 and $10^{\circ}$ ). Interestingly, catchments covered by areas with very steep slopes $\left(>30^{\circ}\right)$ showed very poor correlations with MTTs. Weak correlations were also obtained with catchment drainage density and mean slope length.

Soil WR categories determined along the hillslope transects did not explain much of the variation in baseflow MTTs. Instead, a strong and positive relation was observed between MTT and DSBI; specifically longer stream transit times were related to catchment hillslopes where deep $(>2 \mathrm{~m}$ ) soil-bedrock interfaces dominated (Fig. 5f). Conversely, low and negative correlations were obtained with shallower depths $(<1 \mathrm{~m}$; Table 5). Regardless of the DSBI classes, observed $K_{\mathrm{s}}$ values remained generally high across all sites (5-30 $\mathrm{mm} \mathrm{h}^{-1}$; on average).

Land cover explained a significant variation of the baseflow MTT (Table 5; Fig. 5e); catchments covered by more than $60 \%$ of forests (Categories 1 and 2) had on average the longest MTTs (1.9 $\pm 0.4(\mathrm{SD}) \mathrm{yr})$ compared to catchments dominated by $>90 \%$ of pasture or evenly mixed covers with pasture and forest $(1.5 \pm 0.2 \mathrm{yr}$; Categories 3 and 4$)$.

Baseflow MTT showed no relation to catchment area (Table 5; Fig. 5b). However, at the smallest scale $\left(<0.3 \mathrm{~km}^{2}\right)$, major differences in the MTT were found (1.5 to 2.7 years). At the intermediate scale $\left(4-9 \mathrm{~km}^{2}\right)$, differences in MTTs (1.4 to 1.9 years) were small among catchments. At the larger scale $\left(>14 \mathrm{~km}^{2}\right)$, some more variation in the baseflow MTTs was observed (1.2 to 2 years). The $20 \mathrm{~km}^{2}$ Huehueyapan showed the shortest baseflow transit times (1.2 years) compared to other large catchments examined - this was also the lowest MTT estimated across all the study catchments.

\section{Discussion}

\subsection{How do our baseflow MTTs compare to those found in other tropical montane streams?}

Our stable isotope data showed that wet season rainfall is the main catchment stream water source in this tropical montane region. This is similar to findings in other humid tropical environments (Crespo et al., 2012; Roa García and Weiler, 2010; Scholl and Murphy, 2014), but contrasts with results for temperate regions where seasonality in flow regime is usually much more pronounced and, consequently, stream water tends to reflect input sources from different seasons (Brooks et al., 2012; Mueller et al., 2013; Peralta-Tapia et al., 2015). Our estimates of base flow transit times ranged between 1.2 and 2.7 years across the 12 study catchments. These rather long transit times suggest deep, and presumably 
Table 3. Slope length and gradient, drainage density, form factor, and land cover of the study catchments.

\begin{tabular}{|c|c|c|c|c|c|c|c|c|c|c|}
\hline \multirow[t]{2}{*}{ Catchment } & \multirow{2}{*}{$\begin{array}{l}\text { Mean } \\
\text { slope } \\
\text { length } \\
(\mathrm{m})\end{array}$} & \multirow{2}{*}{$\begin{array}{c}\text { Drainage } \\
\text { density } \\
\left(\mathrm{km} \mathrm{km}^{-2}\right)\end{array}$} & \multirow{2}{*}{$\begin{array}{l}\text { Form } \\
\text { factor } \\
(-)\end{array}$} & \multicolumn{6}{|c|}{$\%$ of cover per slope class } & \multirow{2}{*}{$\begin{array}{l}\text { Land cover category and } \% \text { of } \\
\text { vegetation coverage }\end{array}$} \\
\hline & & & & $0-5^{\circ}$ & $5-10^{\circ}$ & $10-20^{\circ}$ & $20-30^{\circ}$ & $30-45^{\circ}$ & $>45^{\circ}$ & \\
\hline MAT & 123 & 4.8 & 0.222 & 6 & 14 & 35 & 33 & 11 & 1 & [1]: $100 \%$ mature TMCF \\
\hline SEC & 105 & 5.8 & 0.231 & 6 & 14 & 33 & 31 & 15 & 1 & [1]: $100 \%$ secondary TMCF \\
\hline PAS & 68 & 7.0 & 0.164 & 7 & 39 & 36 & 13 & 5 & 0 & [3]: $90 \%$ pasture; $10 \%$ shrubs \\
\hline CATM1 & 80 & 7.9 & 0.071 & 6 & 21 & 28 & 26 & 18 & 1 & $\begin{array}{l}\text { [2]: } 67 \% \text { TMCF; } 31 \% \text { pasture; } \\
2 \% \text { pine-oak forest }\end{array}$ \\
\hline CATM2 & 77 & 8.0 & 0.093 & 6 & 21 & 29 & 26 & 17 & 1 & $\begin{array}{l}\text { [2]: } 66 \% \text { TMCF; } 33 \% \text { pasture; } \\
1 \% \text { pine-oak forest }\end{array}$ \\
\hline CATM3 & 190 & 2.6 & 0.122 & 7 & 30 & 34 & 17 & 11 & 1 & $\begin{array}{l}\text { [4]: } 49 \% \text { pasture; } 36 \% \mathrm{TMCF} \\
15 \% \text { pine-oak forest }\end{array}$ \\
\hline CATM4 & 150 & 3.2 & 0.087 & 6 & 30 & 36 & 17 & 10 & 1 & [4]: $55 \%$ pasture; $34 \%$ TMCF \\
\hline CATM5 & 208 & 6.8 & 0.071 & 9 & 23 & 29 & 20 & 17 & 2 & $\begin{array}{l}\text { [2]: } 55 \% \text { TMCF; } 35 \% \text { pasture; } \\
6 \% \text { pine-oak forest }\end{array}$ \\
\hline CATM6 & 225 & 1.3 & 0.131 & 5 & 15 & 25 & 25 & 25 & 5 & $\begin{array}{l}\text { [2]: } 65 \% \text { TMCF; } 27 \% \text { pasture; } \\
5 \% \text { pine-oak forest }\end{array}$ \\
\hline $\begin{array}{l}\text { PUENTE } \\
\text { ZARAGOZA }\end{array}$ & 235 & 2.9 & 0.187 & 7 & 17 & 26 & 24 & 22 & 4 & $\begin{array}{l}\text { [2]: } 62 \% \text { TMCF; } 29 \% \text { pasture; } \\
5 \% \text { pine-oak forest }\end{array}$ \\
\hline HUEHUEYAPAN & 300 & 2.0 & 0.134 & 13 & 16 & 18 & 21 & 25 & 8 & $\begin{array}{l}\text { [2]: } 43 \% \mathrm{TMCF} ; 29 \% \text { pine-oak } \\
\text { forest; } 21 \% \text { pasture }\end{array}$ \\
\hline LOS GAVILANES & 285 & 2.4 & 0.220 & 9 & 16 & 21 & 22 & 20 & 7 & $\begin{array}{l}\text { [2]: } 51 \% \text { TMCF; } 24 \% \text { pasture; } \\
20 \% \text { pine-oak forest }\end{array}$ \\
\hline
\end{tabular}
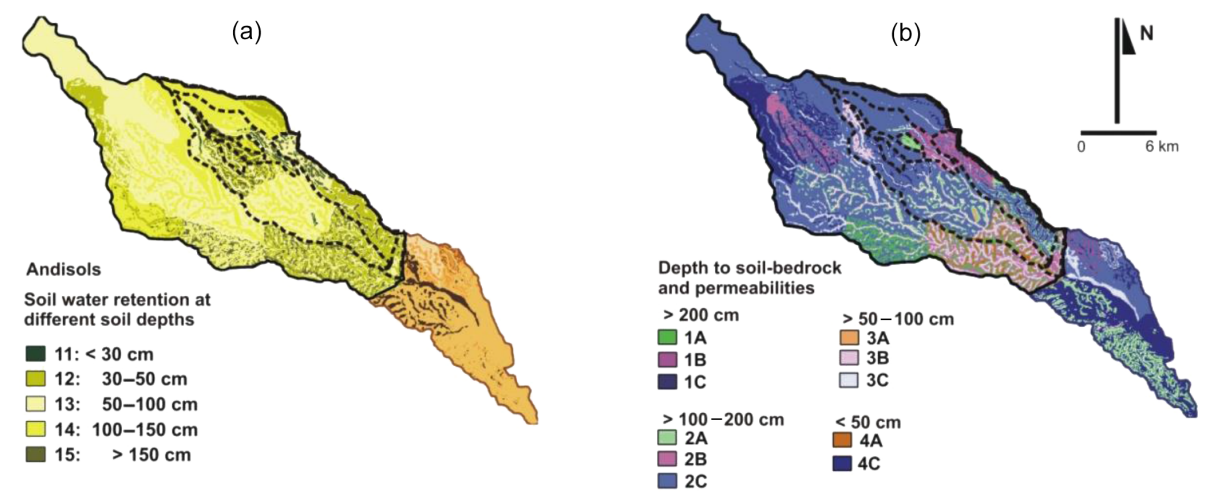

Figure 4. Map of hydro-pedologic properties of the Los Gavilanes river catchment. (a) Soil water retention at field capacity in the solum. Category 11: < $180 \mathrm{~mm}$; category $12: \geq 180 \leq 310 \mathrm{~mm}$; category $13: \geq 310 \leq 580 \mathrm{~mm}$; category $14: \geq 580 \leq 850 \mathrm{~mm}$; and category 15 : $\geq 850 \mathrm{~mm}$; and (b) depth to soil-bedrock interface and corresponding saturated hydraulic conductivities $\left(K_{\mathrm{S}}\right)$. For depth $<100 \mathrm{~cm}, K_{\mathrm{S}}$ categories A, B, and C correspond to $K_{\mathrm{S}}>36 ; 14<K_{\mathrm{S}} \leq 36$ and $1<K_{\mathrm{S}} \leq 14 \mathrm{~mm} \mathrm{~h}^{-1}$, respectively. For depth $>100 \mathrm{~cm}, \mathrm{~A}, \mathrm{~B}$, and C correspond to $K_{\mathrm{S}}>144 ; 36<K_{\mathrm{S}} \leq 144$ and $4<K_{\mathrm{S}} \leq 36 \mathrm{~mm} \mathrm{~h}^{-1}$, respectively.

long, subsurface flow paths contributing to sustain catchment baseflows across scales $\left(0.1\right.$ to $\left.34 \mathrm{~km}^{2}\right)$ and seasons.

Comparing our results with those obtained by Roa-García and Weiler (2010) for three adjacent headwater catchments differing in size $\left(0.6-1.8 \mathrm{~km}^{2}\right)$ and land cover (forest versus pasture) in central-western Colombia, our baseflow MTTs for the cloud forest catchments $\left(\sim 2.7 \mathrm{yr} ; 0.1-0.3 \mathrm{~km}^{2}\right)$ are almost twice the value obtained for their forest-dominated catchment (1.4 years). Further, for two pasture-dominated catchments, these authors obtained MTTs that differed considerably ( 0.1 and 1.4 years), which they attributed to differences in soil permeability. Furthermore, the relatively short 
Table 4. Stream baseflow MTTs, and corresponding model parameters and model efficiencies.

\begin{tabular}{|c|c|c|c|c|c|}
\hline Catchments & MTT & Model* $^{*}$ & Model & & del efficiency \\
\hline MAT & 958 & $\operatorname{Gamma}(\alpha, \beta)$ & $\begin{array}{l}\alpha, \beta \\
0.74(0.70,0.85), \\
1299(524,1137)\end{array}$ & $\begin{array}{c}E \\
0.53\end{array}$ & $\begin{array}{c}\text { RMSE }\left(\delta^{2} \mathrm{H}, \% o\right) \\
1.5\end{array}$ \\
\hline SEC & 975 & $\operatorname{Gamma}(\alpha, \beta)$ & $\begin{array}{l}0.74(0.59,0.93), \\
1326(484,2329)\end{array}$ & 0.68 & 1.4 \\
\hline PAS & 548 & Exponential $\left(\tau_{\mathrm{m}}\right)$ & $\begin{array}{l}\tau_{\mathrm{m}} \\
548(493,609)\end{array}$ & 0.57 & 1.0 \\
\hline CATM1 & 531 & Exponential $\left(\tau_{\mathrm{m}}\right)$ & $\begin{array}{l}\tau_{\mathrm{m}} \\
531(514,550)\end{array}$ & 0.58 & 1.0 \\
\hline CATM2 & 636 & Dispersion $\left(\tau_{\mathrm{m}}, D_{\mathrm{p}}\right)$ & $\begin{array}{l}\tau_{\mathrm{m}}, D_{\mathrm{p}} \\
636(463,824) \\
0.66(0.44,0.89)\end{array}$ & 0.66 & 1.1 \\
\hline CATM3 & 624 & Dispersion $\left(\tau_{\mathrm{m}}, D_{\mathrm{p}}\right)$ & $\begin{array}{l}\tau_{\mathrm{m}}, D_{\mathrm{p}} \\
624(536,734) \\
0.85(0.68,0.96)\end{array}$ & 0.45 & 1.0 \\
\hline CATM4 & 522 & Dispersion $\left(\tau_{\mathrm{m}}, D_{\mathrm{p}}\right)$ & $\begin{array}{l}\tau_{\mathrm{m}}, D_{\mathrm{p}} \\
522(451,571) \\
2.2(1.4,3.0)\end{array}$ & 0.53 & 1.4 \\
\hline CATM5 & 710 & Exponential $\left(\tau_{\mathrm{m}}\right)$ & $\begin{array}{l}\tau_{\mathrm{m}} \\
710(555,859)\end{array}$ & 0.63 & 0.8 \\
\hline CATM6 & 702 & Exponential $\left(\tau_{\mathrm{m}}\right)$ & $\begin{array}{l}\tau_{\mathrm{m}} \\
702(550,856)\end{array}$ & 0.64 & 0.9 \\
\hline $\begin{array}{l}\text { PUENTE } \\
\text { ZARAGOZA }\end{array}$ & 633 & Exponential $\left(\tau_{\mathrm{m}}\right)$ & $\begin{array}{l}\tau_{\mathrm{m}} \\
633(520,751)\end{array}$ & 0.64 & 0.9 \\
\hline HUEHUEYAPAN & 424 & Exponential $\left(\tau_{\mathrm{m}}\right)$ & $\begin{array}{l}\tau_{\mathrm{m}} \\
424(371,482)\end{array}$ & 0.63 & 1.2 \\
\hline LOS GAVILANES & 788 & Exponential $\left(\tau_{\mathrm{m}}\right)$ & $\begin{array}{l}\tau_{\mathrm{m}} \\
788(646,935)\end{array}$ & 0.42 & 1.0 \\
\hline
\end{tabular}

MTT is the mean transit time, $E$ is the Nash-Sutcliffe efficiency, and RMSE is the root mean square error. Numbers in parentheses are the 10 th and 90 th percentile values of the MTT estimates and the model parameters. ${ }^{*}$ Refer to the Supplement for the corresponding formulas of the TTD models.

stream MTTs in the Andean catchments were attributed to the relatively low hydraulic conductivities that characterize the volcanic soils (Acrudoxic Hapludans) of that region, limiting rain water percolation and promoting near-surface flow (Roa-García and Weiler, 2010). This contrasts with our sites, where deep subsurface flow rather than shallow lateral flow is the dominant flow path for runoff generation (Muñoz-Villers and McDonnell, 2012, 2013).

In southern Ecuador, Crespo et al. (2012) used a simple sine-wave approach to estimate the baseflow MTTs for a $74 \mathrm{~km}^{2}$ nested mesoscale watershed (the San Francisco river basin), underlain mostly by Histosols. They found MTTs on the order of 0.7-0.9 years for nine cloud forest catchments $\left(1.3-74 \mathrm{~km}^{2}\right)$. Further, for a $0.8 \mathrm{~km}^{2}$ pasture catchment, they reported a MTT of 0.8 years. Shallow lateral subsurface flow and high catchment runoff ratios (76-81\%) due to relatively low topsoil and subsurface permeabilities $\left(14-166 \mathrm{~mm} \mathrm{~h}^{-1}\right)$ characterized the hydrology of that montane area (Crespo et al., 2012). In contrast, soil hydraulic conductivities at our site were higher $\left(\sim 400 \mathrm{~mm} \mathrm{~h}^{-1}\right.$ on average across land covers; Muñoz-Villers et al., 2015), leading to lower (annual) rainfall-runoff ratios (35-50\%), and hydrological responses mainly driven by groundwater sources, which likely explain the much larger catchment water storage capacities of our systems.

For eight of the catchments in the San Francisco river basin previously investigated by Crespo et al. (2012), Timbe et al. (2014) obtained much higher MTT values by fitting sev- 
Table 5. Spearman's rank correlation coefficients $\left(r_{\mathrm{s}}\right)$ between baseflow MTT and land cover, catchment area, topographic characteristics, and subsurface hydrologic properties for the study catchments.

\begin{tabular}{lr}
\hline & $r_{\mathrm{s}}$ \\
\hline Land cover & -0.74 \\
Area $\left(\mathrm{km}^{2}\right)$ & -0.09 \\
Form factor $(-)$ & 0.56 \\
Drainage density $\left(\mathrm{km} \mathrm{km}^{-2}\right)$ & 0.05 \\
Mean slope length $(\mathrm{m})$ & -0.13 \\
Slope $0-5^{\circ}$ & -0.22 \\
Slope $5-10^{\circ}$ & -0.63 \\
Slope $10-20^{\circ}$ & -0.01 \\
Slope $20-30^{\circ}$ & 0.57 \\
Slope $30-45^{\circ}$ & 0.04 \\
Slope $>45^{\circ}$ & 0.06 \\
DSBI $>200 \mathrm{~cm}$ & 0.48 \\
$100<$ DSBI $\leq 200 \mathrm{~cm}$ & -0.28 \\
$50<$ DSBI $\leq 100 \mathrm{~cm}$ & -0.15 \\
DSBI $\leq 50 \mathrm{~cm}$ & -0.08 \\
\hline Soil WR per category & \\
\hline 11 & -0.08 \\
12 & 0.24 \\
13 & -0.18 \\
14 & 0.30 \\
15 & -0.25 \\
\hline
\end{tabular}

eral TTD models. For seven cloud forest dominated catchments $\left(1.3-77 \mathrm{~km}^{2}\right)$, they reported an average MTT value of 2.1 years, while for a pasture catchment they obtained a MTT value (3.9 years) that was twice the average value for the forests. However, the authors did not provide an explanation of why they found longer MTTs and contradictory results (i.e., higher MTT in the pasture than in the forests) compared to the earlier work by Crespo et al. (2012).

\subsection{Factors determining baseflow MTTs in this tropical montane watershed}

It is well known that topography plays an important role in the transit time of water through catchments (Tetzlaff et al., 2009a), particularly in montane environments (cf. McGuire et al., 2005). Our findings are consistent with previous work and show that the longest baseflow MTTs are related to rounded shapes of catchment $(0.19-0.23)$, where moderate slope gradients $\left(20-30^{\circ}\right)$ predominate. In contrast, catchments with elongated forms - regardless of their internal slope assemblages - produced the shortest MTT estimates. Our interpretation is that in narrow forms, the hydrological connectivity between hillslopes and the stream is higher than in catchments with more rounded shapes. This in turn would increase the frequency of water table formation and response to precipitation leading to shorter water travel times. Related work on this was carried out by Hrachowitz et al. (2009)
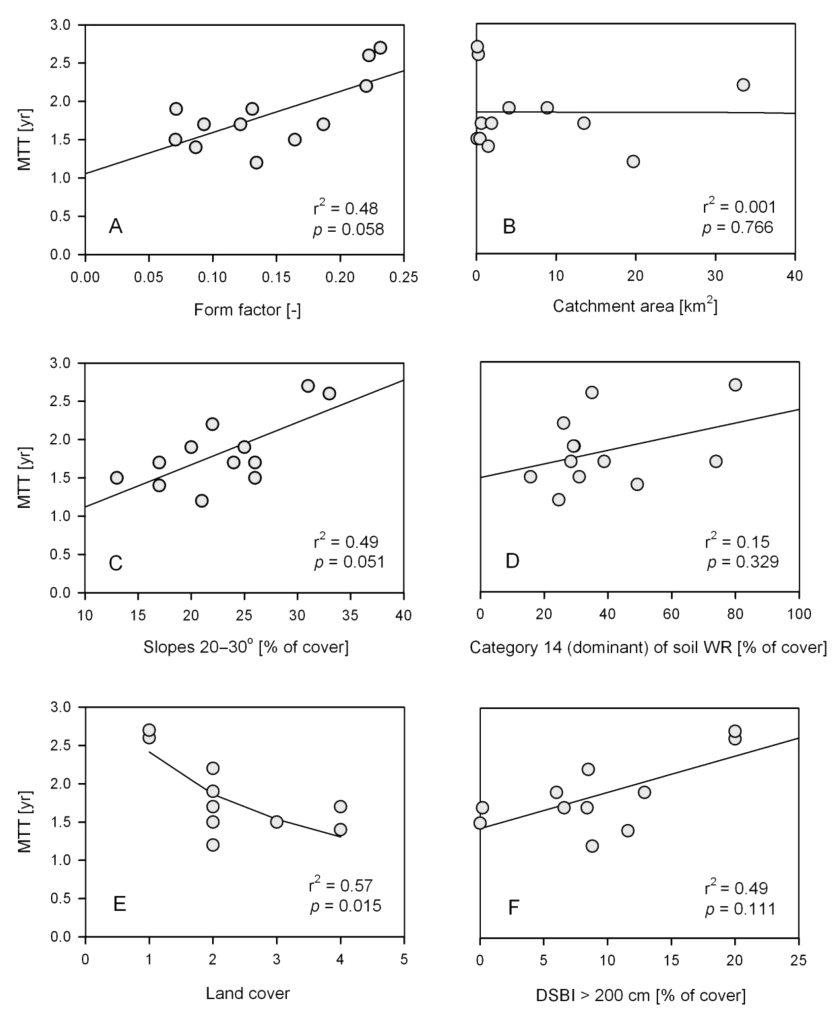

Figure 5. Regressions between stream baseflow MTTs and topographic features, subsurface properties, land cover, and catchment area for the study catchments.

in the Scottish Highlands, who evaluated the influence of topography on stream MTT. In their study, form factor ratios and drainage densities were computed for 20 different catchments $\left(<1\right.$ to $35 \mathrm{~km}^{2}$ ). Their work showed that elongated forms of catchments were roughly distinguished from rounded shapes. Drainage density, however, characterized much better the catchments topography of that region showing a strong and inverse relationship with stream MTTs. They found high drainage density values associated with high percentages of responsive soil cover (peat soils) as rapid water routed via overland flow enhances connectivity between hillslopes and stream channel network. In our study site, drainage density was inversely related to slope length (data not shown) and showed no correlation with soil type as Andisols dominate entirely the hillslopes of our catchments.

We also explored the influences of land cover on baseflow MTT. Our findings showed that catchments covered predominantly by forests had longer MTT estimates compared to catchments dominated by pasture. We attributed this to topographic differences among sites more than land cover effects since most forested areas are themselves located on steep terrain. This is supported by results obtained by Muñoz-Villers and McDonnell (2013), who investigated the streamflow dynamics at the mature and secondary TMCF and pasture headwater catchments. They found on average $50 \%$ lower base- 
flow in the pasture at the end of the dry season compared to forests, explained by lower recharge of subsurface water storages due to smaller catchment gradients (cf. Sayama et al., 2011; Tetzlaff et al., 2009b) in the pasture, and lower surface soil infiltration capacities caused by animal grazing compaction $\left(30 \pm 14 \mathrm{~mm} \mathrm{~h}^{-1}\right.$ versus $\left.696 \pm 810 \mathrm{~mm} \mathrm{~h}^{-1}\right)$. Thus, the fact that forested catchments have steeper slopes and higher topsoil infiltration capacities might be a more likely explanation for their higher subsurface water storage capacities.

In general, very few studies have investigated the effect of land cover on catchment stream MTTs. Mueller et al. (2013) studied the influence of shrub cover area on MTTs in four micro catchments in the Swiss Alps. They found that soil and bedrock hydraulic characteristics had a stronger control on stream transit times rather than land cover. High subsurface flow promoted by fast soil water percolation through fractured bedrock, which can contain karstic rock in deeper layers, dominated the catchment water storage, mixing and release in this alpine environment. More recently, Geris et al. (2015) investigated the relative influence of soil type and vegetation cover on storage and transmission processes in a headwater catchment $\left(3.2 \mathrm{~km}^{2}\right)$ in northeast Scotland. Forested and non-forested sites were compared on poorly drained Histosols in riparian zones and freely draining Podzols on steeper hillslopes. Their results showed that soil permeability properties linked to soil type rather than vegetation influences were dominant features on water storage dynamics at the plot and catchment scales.

Our study determined the depth and permeability of the soil-bedrock interface through intensive and extensive measurements in the subsurface over numerous hillslope transects across the LG catchment. This is rather unlike most studies that have derived flow path depths and source contributing areas to stream discharge from surface topography based on digital terrain models (Hrachowitz et al., 2010; McGuire et al., 2005; Tetzlaff et al., 2009b) or from geochemical tracers such as $\mathrm{SiO}_{2}$ (Asano and Uchida, 2012). Our approach showed that hillslopes with deeper soils along with high hydraulic conductivities at the soil-bedrock interface allowed more subsurface water transmission and storage, leading to longer catchment baseflow transit times. In this case, the longest stream MTTs (ca. 3 years) were obtained in the mature and secondary TMCF headwater catchments, associated with their highest percentage of area covered by deep soil-bedrock profiles related in turn to their moderate steep relief, and greatest subsurface permeabilities. Previous work at these sites showed that the very high permeability of the Andisols $\left(1000 \mathrm{~mm} \mathrm{~h}^{-1}\right.$ at $0.1 \mathrm{~m}$ to $4 \mathrm{~mm} \mathrm{~h}^{-1}$ at $1.5 \mathrm{~m}$ depth; Karlsen, 2010) and underlying volcanic substrate promote vertical and fast soil water percolation and recharge of deeper sources, as the preferred flow path mechanism controlling catchment water storage and storm runoff responses (Muñoz-Villers and McDonnell, 2013).
Across all catchments, the observed range of saturated hydraulic conductivities at the soil-bedrock interface was from 5 to $30 \mathrm{~mm} \mathrm{~h}^{-1}$, suggesting little impedance for water to continue percolating vertically below the soil profile and to recharge groundwater reservoirs. This could explain the generally long MTTs found across sites (1.8 years on average). Further, we observed the greatest depths to bedrock at mid- and ridge-top hillslope positions (data not shown). Thus these topographic features seem to be the main contributing areas to subsurface water recharge. While soil water retention capacities were also greatest at mid- and ridge-top hillslope positions, they did not explain much of the variation in baseflow MTTs.

These findings are partly consistent with those obtained by Asano and Uchida (2012) in central Japan, who examined the baseflow MTT spatial variation for a $4.3 \mathrm{~km}^{2}$ forested montane watershed underlain by granitic soils. They used the dampening of the isotopic signal as a proxy for the relative difference in MTTs among locations. They also used dissolved silica as a tracer to identify the contributing depth of the flow path to stream discharge. Their work showed that the depth of hydrologically active soil-bedrock layer was the main factor determining catchment water storage. Longer baseflow MTT were associated with increased flow path contributions related in turn to hillslope length and topography. McGuire et al. (2005) also showed strong correlations between catchment terrain indices (flow path length) and mean stream residence times for seven catchments $(0.085-$ $62.4 \mathrm{~km}^{2}$ ) in the western Cascade Range of Oregon, USA, showing that landscape organization was the main factor controlling catchment-scale water transport.

While some investigations have reported that catchment area controls the variation in stream MTT (i.e., Hale and McDonnell, 2016; McGlynn et al., 2003), the majority of the work published to date has shown no relation between MTT and catchment size for catchments ranging between 0.1 and $200 \mathrm{~km}^{2}$ (Crespo et al., 2012; McGuire et al., 2005; Mueller et al., 2013; Rodgers et al., 2005; Soulsby et al., 2006). Our findings support these latter studies and show that increasing catchment area does not lead to longer mean stream travel times.

We also found that baseflow MTTs were more variable in smaller catchments $\left(0.1-1.5 \mathrm{~km}^{2}\right.$ sizes) where topography imposed its strongest effect (cf. Hrachowitz et al., 2010; Tetzlaff et al., 2009b). Further, longer MTT were found at the forest-dominated headwater catchments $\left(\leq 0.25 \mathrm{~km}^{2}\right.$; $\sim 3 \mathrm{yr}$ ). This is similar to the findings obtained by Timbe et al. (2014) in a tropical montane cloud forest watershed underlain by Histosols in southern Ecuador, who reported longer and larger variation of MTTs in small streams (0.1$5 \mathrm{~km}^{2} ; \sim 3 \pm 1.09 \mathrm{yr}$ ) in comparison to downstream tributaries and main river channels $\left(10-77 \mathrm{~km}^{2} ; \sim 2 \pm 0.08 \mathrm{yr}\right)$. At the intermediate scale (4-9 km²), our differences in MTTs were small and associated probably with catchment topography. Unexpectedly, MTTs showed a slight convergent pattern 
at this scale (Fig. 5b) (cf. Hrachowitz et al., 2010; Timbe et al., 2014). Beyond this scale $\left(>9 \mathrm{~km}^{2}\right)$, catchment processes determining streamflow behavior seems to be different. For instance, the Huehueyapan watershed $\left(20 \mathrm{~km}^{2}\right)$ showed the shortest MTT (1.2 years) across all catchments investigated. We attributed its low water storage capacity to its narrow form, combination of gentle and very steep slope areas (the latter limiting the development of soil on its hillslopes), and shallow depths to bedrock. Alternatively, the main outlet of the LG catchment $\left(35 \mathrm{~km}^{2}\right)$ has an MTT of 2.2 years that nearly doubled the MTT value of its main tributary (Huehueyapan catchment). This might suggest that runoff processes of smaller catchments does not necessary combine to define MTT at larger scales $\left(>14 \mathrm{~km}^{2}\right)$ (cf. Shaman et al., 2004), probably due to changes in geomorphology, related in turn to past landscape formation of this volcanic area.

\section{Conclusions}

This study provides an important first step towards a better understanding of the hydrology of tropical montane regions and the factors influencing stream water transit times in these environments. Our estimates of baseflow MTT ranged between 1.2 and 2.7 years across 12 catchments (0.1 to $34 \mathrm{~km}^{2}$ ) in central Veracruz, Mexico, suggesting deep and presumably long subsurface flow paths contributing to sustain baseflows, particularly during dry periods. Our findings showed that catchment slope and the permeability observed at the soil-bedrock interface are the key factors controlling baseflow MTT in this tropical montane region. The longest stream MTTs were found in the cloud forest headwater catchments, related to their moderate steep slopes, and greater transmissivity at the soil-bedrock interface. Conversely, the MTT was shortest in one tributary of the main river outlet, which was mainly attributed to its high proportions of both gentle and very steep slopes. In association with topography, catchment form and the depth to the soilbedrock interface were also identified as important features influencing baseflow MTT variability across scales. More specifically, longer baseflow MTTs appeared to be related to rounded shapes of catchments and deeper soil-bedrock interfaces. The greatest depths to bedrock were particularly observed in the mid- and ridge-top hillslope positions; thus, these topographic locations seemed to be the main contributing areas for catchment subsurface water recharge. Major differences in MTTs were found both within groups of small $\left(0.1-1.5 \mathrm{~km}^{2}\right)$ and large $\left(14-34 \mathrm{~km}^{2}\right)$ catchments, related mostly to catchment slope and morphology, and to much lesser extent to land cover.

The Supplement related to this article is available online at doi:10.5194/hess-20-1621-2016-supplement.
Author contributions. Lyssette E. Muñoz-Villers and Jeffrey J. McDonnell developed the idea of this research. Lyssette E. MuñozVillers, Daniel R. Geissert, and Friso Holwerda collected data. Lyssette E. Muñoz-Villers and Daniel R. Geissert analyzed and interpreted data. Lyssette E. Muñoz-Villers wrote the first draft of the manuscript. Daniel R. Geissert and Friso Holwerda edited and commented on this first draft. Daniel R. Geissert and Jeffrey J. McDonnell edited and commented on the second draft and the final version.

Acknowledgements. We thank the Municipality of Coatepec (Veracruz, Mexico) and the residents of Plan de San Antonio, Loma Alta, and Tierra Grande for permitting us to work on their land. Tina Garland and Caroline Patrick are thanked for their assistance in analyzing the water samples for isotopes. Adán Hernández, Sergio Cruz, Luiz Martínez, and Enrique Meza are thanked for their great help in the field. We appreciate the valuable comments of two anonymous reviewers. Finally, this research was founded by the US National Science Foundation (NSF/DEB 0746179) grant to H. Asbjornsen, T. E. Dawson, and J. J. McDonnell, and by Mexico-CONACyT (CB-106788) grant to D. R. Geissert.

Edited by: F. Tian

\section{References}

Asano, Y. and Uchida, T.: Flow path depth is the main controller of mean baseflow transit times in a mountainous catchment, Water Resour. Res., 48, W03512, doi:10.1029/2011WR010906, 2012.

Asner, G. P., Rudel, T. K., Aide, T. M., Defries, R., and Emerson, R.: A contemporary assessment of change in humid tropical forests, Conserv. Biol., 26, 1386-1395, 2009.

Boorman, D. B., Hollis, J. M., and Lilly, A.: Hydrology of soil types: a hydrologically-based classification of the soils of the United Kingdom, Inst. Hydrol., Wallingford, 26-37, 1995.

Brooks, J. R., Wigington, P. J., Phillips, D. L., Comeleo, R., and Coulombe, R.: Willamette River Basin surface water isoscape $\left(\delta^{18} \mathrm{O}\right.$ and $\left.\delta^{2} \mathrm{H}\right)$ : temporal changes of source water within the river, Ecosphere, 3, 1-21, 2012.

Broxton, P. D., Troch, P. A., and Lyon, S. W.: On the role of aspect to quantify water transit times in small mountainous catchments, Water Resour. Res., 45, W08427, doi:10.1029/2008WR007438, 2009.

Bruijnzeel, L. A.: Hydrological functions of tropical forests: Not seeing the soil for the trees?, Agr. Ecosyst. Environ., 104, 185228, 2004.

Carey, S. K., Tetzlaff, D., Seibert, J., Soulsby, C., Buttle, J., Laudon, H., McDonnell, J., McGuire, K., Caissie, D., Shanley, J., Kennedy, M., Devito, K., and Pomeroy, J. W.: Intercomparison of hydro-climatic regimes across northern catchments: synchronicity, resistance and resilience, Hydrol. Process., 24, 3591-3602, 2010.

Cayuela, L., Golicher, D. J., and Rey-Benayas, J. M.: The extent, distribution, and fragmentation of vanishing montane cloud forest in the Highlands of Chiapas, Mexico, Biotropica, 38, 544554, 2006.

Crespo, P., Bücker, A., Feyen, J., Vaché, K. B., Frede, H.-G., and Breuer, L.: Preliminary evaluation of the runoff processes in a 
remote montane cloud forest basin using Mixing Model Analysis and Mean Transit Time, Hydrol. Process., 26, 3896-3910, 2012.

Dansgaard, W.: Stable Isotopes in Precipitation, Tellus, 16, 436468, 1964.

Freer, J., Beven, K., and Ambroise, B.: Bayesian estimation of uncertainty in runoff prediction and the value of data: An application of the GLUE approach, Water Resour. Res., 32, 2161-2173, 1996.

Garcia, E.: Modificaciones al sistema de clasificación climática de Köppen, Offset Larios, México, D. F., México, 217 pp., 1988.

Geris, J., Tetzlaff, D., Mcdonnell, J., and Soulsby, C.: The relative role of soil type and tree cover on water storage and transmission in northern headwater catchments, Hydrol. Process., 29, 18441860, 2015.

Goldsmith, G. R., Muñoz-Villers, L. E., Holwerda, F., McDonnell, J. J., Asbjornsen, H., and Dawson, T. E.: Stable isotopes reveal linkages among ecohydrological processes in a seasonally dry tropical montane cloud forest, Ecohydrology, 5, 779-790, 2012.

Gómez-Tagle Jr., A., Geissert, D., Pérez-Maqueo, O. M., MarinCastro, B. E., and Rendon-Lopez, M. B.: Saturated hydraulic conductivity and land use change, new insights to the payments for ecosystem services programs: a case study from a tropical montane cloud forest watershed in Eastern Central Mexico, in: Developments in Hydraulic Conductivity Research, edited by: Dikinya, O., InTech, Rijeka, Croatia, 225-247, 2011.

Hale, V. C. and McDonnell, J. J.: Effect of bedrock permeability on stream baseflow mean transit time scaling relations: (1) A multi-scale catchment intercomparison, Water Resour. Res., doi:10.1002/2014WR016124, in press, 2016.

Hamilton, L. S., Juvik, J. O., and Scatena, F. N. (Eds.): The Puerto Rico tropical montane cloud forest symposium: introduction and workshop synthesis, in: Tropical Montane Cloud Forests, Ecological Studies, Springer, Verlag, New York, 1-16, 1995.

Herrick, J. E. and Jones, T. L.: A dynamic cone penetrometer for measuring soil penetration resistance, Soil Sci. Soc. Am. J., 66, 1320-1324, 2002.

Holwerda, F., Bruijnzeel, L. A., Muñoz-Villers, L. E., Equihua, M., and Asbjornsen, H.: Rainfall and cloud water interception in mature and secondary lower montane cloud forests of central Veracruz, Mexico, J. Hydrol., 384, 84-96, 2010.

Holwerda, F., Bruijnzeel, L. A., Barradas, V. L., and Cervantes, J.: The water and energy exchange of a shaded coffee plantation in the lower montane cloud forest zone of central Veracruz, Mexico, Agr. Forest Meteorol., 173, 1-13, 2013.

Horton, R. E.: Drainage-basin characteristics, EOS T. Am. Geophys. Un., 13, 350-361, 1932.

Hrachowitz, M., Soulsby, C., Tetzlaff, D., Dawson, J. J. C., Dunn, S. M., and Malcolm, I. A.: Using long-term data sets to understand transit times in contrasting headwater catchments, J. Hydrol., 367, 237-248, 2009.

Hrachowitz, M., Soulsby, C., Tetzlaff, D., and Speed, M.: Catchment transit times and landscape controls - does scale matter?, Hydrol. Process., 24, 117-125, 2010.

Jenness, J.: Topographic Position Index (tpi_jen.avx) extension for ArcView 3.x, v. 1.3a, Jenness Enterprises, Flagstaff, AZ, USA, 1-42, 2006.

Karlsen, R.: Stormflow processes in a mature tropical montane cloud forest catchment, Coatepec, Veracruz, Mexico, MSc thesis, VU Univ., Amsterdam, the Netherlands, 110 pp., 2010.
Maloszewski, P. and Zuber, A.: Determining the turnover time of groundwater systems with the aid of environmental tracers. 1. Models and their applicability, J. Hydrol., 57, 207-231, 1982.

Maloszewski, P. and Zuber, A.: Tracer experiments in fractured rocks: Matrix diffusion and validity of models, Water Resour. Res., 8, 2723-2735, 1993.

McDonnell, J. J., McGuire, K., Aggarwal, P., Beven, K. J., Biondi, D., Destouni, G., Dunn, S., James, A., Kirchner, J., Kraft, P., Lyon, S., Maloszewski, P., Newman, B., Pfister, L., Rinaldo, A., Rodhe, A., Sayama, T., Seibert, J., Solomon, K., Soulsby, C., Stewart, M., Tetzlaff, D., Tobin, C., Troch, P., Weiler, M., Western, A., Wörman, A., and Wrede, S.: How old is streamwater? Open questions in catchment transit time conceptualization, modelling and analysis, Hydrol. Process., 24, 1745-1754, 2010.

McGlynn, B., McDonnell, J., Stewart, M., and Seibert, J.: On the relationships between catchment scale and streamwater mean residence time, Hydrol. Process., 17, 175-181, 2003.

McGuire, K. J. and McDonnell, J. J.: Hydrological connectivity of hillslopes and streams: Characteristic time scales and nonlinearities, Water Resour. Res., 46, W10543, doi:10.1029/2010WR009341, 2010.

McGuire, K. J., McDonnell, J. J., Weiler, M., Kendall, C., McGlynn, B. L., Welker, J. M., and Seibert, J.: The role of topography on catchment scale water residence time, Water Resour. Res., 41, W05002, doi:10.1029/2004WR003657, 2005.

Mueller, M. H., Weingartner, R., and Alewell, C.: Importance of vegetation, topography and flow paths for water transit times of base flow in alpine headwater catchments, Hydrol. Earth Syst. Sci., 17, 1661-1679, doi:10.5194/hess-17-1661-2013, 2013.

Muñoz-Villers, L. E. and López-Blanco, J.: Land use/cover changes using Landsat TM/ETM images in a tropical and biodiverse mountainous area of central eastern Mexico, Int. J. Remote Sens., 29, 71-93, 2008.

Muñoz-Villers, L. E. and McDonnell, J. J.: Runoff generation in a steep, tropical montane cloud forest catchment on permeable volcanic substrate, Water Resour. Res., 48, W09528, doi:10.1029/2011WR011316, 2012.

Muñoz-Villers, L. E. and McDonnell, J. J.: Land use change effects on runoff generation in a humid tropical montane cloud forest region, Hydrol. Earth Syst. Sci., 17, 3543-3560, doi:10.5194/hess17-3543-2013, 2013.

Muñoz-Villers, L. E., Holwerda, F., Gómez-Cárdenas, M., Equihua, M., Asbjornsen, H., Bruijnzeel, L. A., Marín-Castro, B. E., and Tobón, C.: Water balances of old-growth and regenerating montane cloud forests in central Veracruz, Mexico, J. Hydrol., 462463, 53-66, 2012.

Muñoz-Villers, L. E., Holwerda, F., Alvarado-Barrientos, M. S., Geissert, D., Marín-Castro, B. E., Gómez-Tagle, A., McDonnell, J. J., Asbjornsen, H., Dawson, T. E., and Bruijnzeel, L. A.: Efectos hidrológicos de la conversión del bosque de niebla en el centro de Veracruz, México, Bosque, 36, 395-407, 2015.

Nash, J. E. and Sutcliffe, J. V.: River flow forecasting through conceptual models, I, A discussion of principles, J. Hydrol., 10, 282 290, 1970.

NRCS-USDA: National Engineering Handbook, Part 630, chap. 7, Hydrologic Soil Groups, Washington, D.C., USA, 1-5, 2007.

Peralta-Tapia, A., Sponseller, R. A., Tetzlaff, D., Soulsby, C., and Laudon, H.: Connecting precipitation inputs and soil flow path- 
ways to stream water in contrasting boreal catchments, Hydrol. Process., 29, 3546-3555, 2015.

Pope, I., Bowen, D., Harbor, J., Shao, G., Zanotti, L., and Burniske, G.: Deforestation of montane cloud forest in the Central Highlands of Guatemala: contributing factors and implications for sustainability in Q'eqchi' communities, Int. J. Sust. Dev. World, 22, 201-212, 2015.

Roa-García, M. C. and Weiler, M.: Integrated response and transit time distributions of watersheds by combining hydrograph separation and long-term transit time modeling, Hydrol. Earth Syst. Sci., 14, 1537-1549, doi:10.5194/hess-14-1537-2010, 2010.

Rodgers, P., Soulsby, C., Waldron, S., and Tetzlaff, D.: Using stable isotope tracers to assess hydrological flow paths, residence times and landscape influences in a nested mesoscale catchment, Hydrol. Earth Syst. Sci., 9, 139-155, doi:10.5194/hess-9-139-2005, 2005.

Sayama, T., McDonnell, J. J., Dhakal, A., and Sullivan, K.: How much water can a watershed store?, Hydrol. Process., 25, 38993908, 2011.

Schoeneberger, P. J., Wysocki, D. A., Benham, E. C., and Broderson, W. D.: Field book for describing and sampling soils, Version 2.0, National Soil Survey Center, Natural Resources Conservation Service, USDA, Lincoln, NE, USA, 45-164, 2002.

Scholl, M. A. and Murphy, S. F.: Precipitation isotopes link regional climate patterns to water supply in a tropical mountain forest, eastern Puerto Rico, Water Resour. Res., 50, 4305-4322, 2014.

Seibert, J. and McDonnell, J. J.: Land-cover impacts on streamflow: A change-detection modelling approach that incorporates parameter uncertainty, Hydrolog. Sci. J., 55, 316-332, 2010.
Shaman, J., Stieglitz, M., and Burns, D.: Are big basins just the sum of small catchments?, Hydrol. Process., 18, 3195-3206, 2004.

SMN: http://smn.cna.gob.mx/ (last access: 31 August 2015), 2014.

Soulsby, C., Tetzlaff, D., Rodgers, P., Dunn, S., and Waldron, S.: Runoff processes, stream water residence times and controlling landscape characteristics in a mesoscale catchment: An initial evaluation, J. Hydrol., 325, 197-221, 2006.

Tetzlaff, D., Seibert, J., McGuire, K. J., Laudon, H., Burn, D. A., Dunn, S. M., and Soulsby, C.: How does landscape structure influence catchment transit time across different geomorphic provinces?, Hydrol. Process., 23, 945-953, 2009a.

Tetzlaff, D., Seibert, J., and Soulsby, C.: Inter-catchment comparison to assess the influence of topography and soils on catchment transit times in a geomorphic province; the Cairngorm mountains, Scotland, Hydrol. Process., 23, 1874-1886, 2009 b.

Timbe, E., Windhorst, D., Crespo, P., Frede, H.-G., Feyen, J., and Breuer, L.: Understanding uncertainties when inferring mean transit times of water trough tracer-based lumped-parameter models in Andean tropical montane cloud forest catchments, Hydrol. Earth Syst. Sci., 18, 1503-1523, doi:10.5194/hess-18-15032014, 2014.

Weiler, M., McGlynn, B. L., McGuire, K. J., and McDonnell, J. J.: How does rainfall become runoff? A combined tracer and runoff transfer function approach, Water Resour. Res., 39, 1315, doi:10.1029/2003WR002331, 2003. 